\title{
A teoria do conhecimento de Antônio Pedro de Figueiredo ${ }^{1}$
}

\section{Antônio Pedro de Figueiredo's theory of knowledge}

\author{
Paulo Margutti \\ https://orcid.org/0000-0002-5405-0869 - E-mail: pmargutti290@gmail.com
}

\begin{abstract}
RESUMO
O presente artigo apresenta a teoria do conhecimento de Antônio Pedro de Figueiredo, com o objetivo de divulgar suas ideias e estimular o estudo de seu pensamento. Para tanto, expõe inicialmente as informações sobre a vida e a obra de Figueiredo. Em seguida, passa para a apresentação de suas ideias nos artigos Certeza Humana e Processos Lógicos do Espírito Humano. Depois disso, desenvolve uma interpretação detalhada da teoria do conhecimento presente nesses artigos. Ao final, é feito um rápido balanço dos resultados apresentados, na expectativa de que o artigo tenha despertado a atenção das pessoas para o pensamento de Figueiredo.
\end{abstract}

Palavras-chave: Figueiredo. Teoria do conhecimento. Filosofia brasileira.

\begin{abstract}
The current paper presents Antonio Pedro de Figueiredo's theory of knowledge, with the purpose to divulge his ideas and motivate the study of his thought. For that matter, informations about Figueiredo's life and works are initially exposed. In what follows, his ideas in the texts Certeza Humana (On Human Certainty) and Processos Lógicos do Espírito Humano (Logical Processes of Human Mind) are presented. After that, a more detailed interpretation of the theory of knowledge as exposed in those texts is developed. In the end, a quick evaluation of the re-

\footnotetext{
1 O presente artigo constitui um extrato de parte do $3^{\circ}$ volume de nossa História da Filosofia do Brasil, em fase de redação. Foram feitas adaptações e acréscimos para adequá-lo ao formato de um artigo.
} 
sults obtained is made, in the expectation that people's attention to Figueiredo's thought has been awakened.

Keywords: Figueiredo. Theory of knowledge. Brazilian philosophy.

\section{Observações iniciais}

Antes de qualquer coisa, gostaríamos de parabenizar a revista Argumentos pela iniciativa de publicar um Dossiê sobre a Filosofia Brasileira. Trata-se de mais um louvável passo dado na direção de uma renovação dos estudos do pensamento de nossos conterrâneos, num contexto cultural geralmente desinteressado por esse assunto. No presente artigo, dedicaremos a atenção à teoria do conhecimento de Antônio Pedro de Figueiredo, um autor brasileiro do s. XIX que ficou esquecido por muitos anos. O interesse pelo seu trabalho ressurgiu a partir do livro Nordeste, de Gilberto Freyre, publicado em 1937. Nesse livro, o autor de Casa grande e senzala descreve Figueiredo como um mulato nordestino que exerceu no s. XIX a crítica das ideias e a crítica social de modo surpreendente. Para Freyre, ele foi um revolucionário intelectual que fez uma tradução minuciosa do Curso de Cousin e que criticou a organização patriarcal do país. Freyre considera Figueiredo mais interessante do que Natividade Saldanha e Tobias Barreto para o estudo da história intelectual do nordeste, apesar de ser vítima de um desmerecido esquecimento. ${ }^{2}$ Depois da recomendação de Freyre, diversos autores se interessaram pelas ideias de Figueiredo, destacando-se, entre outros, Amaro Quintas, Vamireh Chacon, Tiago Adão Lara e Georges Orsoni.

Como pudemos constatar, trata-se de um autor importante, que merece um lugar de destaque na filosofia brasileira do s. XIX. No presente artigo, como informamos, concentraremos a atenção na teoria do conhecimento de Figueiredo, que possui características originais. Para levar adiante essa tarefa, iremos apresentar inicialmente alguns fatos importantes de sua biografia e de sua obra, passando em seguida para a apresentação da sua teoria do conhecimento tal como exposta nos textos relevantes. Depois disso, apresentaremos nossa interpretação de tal teoria, mostrando sua originalidade e suas relações com as ideias de autores estrangeiros ligados de alguma maneira a essa teoria. Finalmente, na parte final, listaremos algumas conclusões a respeito de Figueiredo e suas ideias no campo considerado. Nosso objetivo aqui é divulgar as ideias de um importante pensador brasileiro do s. XIX, estimulando o desenvolvimento de estudos mais detalhados a seu respeito. Por razões de espaço, deixaremos de lado outros aspectos importantes de seu pensamento e também não avaliaremos sua teoria do conhecimento aqui, restringindo-nos à apresentação da mesma.

\section{Vida e obra de Figueiredo}

Antônio Pedro de Figueiredo (1814?-1859) Nasceu em Igaraçu, na Província de Pernambuco. ${ }^{3}$ Era mulato e de origem humilde. Com base em uma promessa de auxílio de um

\footnotetext{
2 Ver (FREYRE, 1985, p. 134-5;157). (A cópia que conseguimos está em formato pdf, sem numeração das páginas. Os números indicados correspondem à paginação do arquivo em pdf). Ver também (FREYRE, 1940), que também faz referências a Figueiredo, mas ao qual infelizmente não tivemos acesso.

${ }^{3}$ Sacramento Blake indica 1822 como o ano do nascimento de Figueiredo (SACRAMENTO BLAKE, 1901, p. 276). Mas Tiago Adão Lara levanta a hipótese de que Figueiredo teria nascido em 1814 e não em 1822, uma vez que faleceu aos 45 anos de idade (LARA, 2001, p. 29). Wilson Martins também indica 1814 como a data de nascimento de Figueiredo (MARTINS, 1992, p. 342).
} 
amigo, mudou-se para Recife. O amigo, porém, não cumpriu a promessa e o abandonou. Conseguiu então abrigo no Convento do Carmo, onde encontrou condições para estudar humanidades por conta própria, tendo inclusive aprendido francês como autodidata. Era briIhante, mas teve de contentar-se com o autodidatismo. Embora não tivesse título acadêmico, era respeitado por sua cultura pelos amigos. Em 1844, caiu nas graças de Francisco do Rego Barros, no início Barão e depois Conde da Boa Vista, que era conservador e presidente da província de Pernambuco na época. ${ }^{4}$ Graças a isso, foi nomeado professor adjunto do Liceu de Provincial provavelmente aos 30 anos de idade, tendo ali lecionado geometria, português, geografia e história. Foi também por diversas vezes examinador do curso preparatório, anexo à Faculdade de Recife. Sua situação mudou por ocasião da mudança de presidente da província, em 1846, quando o liberal Antônio Chichorro da Gama, membro do Partido da Praia, assumiu o poder em Pernambuco. Nessa ocasião, criou, com mais três amigos, O Progresso, revista social, política, literária e científica, destinada a despertar a opinião pública a respeito das necessidades do país e dos desmandos do governo praieiro. Mas nessa mesma época foi demitido do Liceu Provincial, em virtude de suas ligações com Rego Barros. Seus amigos protestaram contra a demissão em O Progresso, num artigo intitulado Variedades, mas sem sucesso. Esse ato administrativo foi visto como confirmação da política mesquinha que dominava a província. Em 1847, com o término do mandato de Chichorro da Gama, surgiu um clima de instabilidade em Pernambuco, que culminou com a Revolução Praieira. Em 1848, Figueiredo foi redator do periódico político $O$ Parlamentar, que teve curta duração, com apenas cinco números publicados entre 01 de junho e 01 de julho do mesmo ano. O mote do jornal era a seguinte máxima do marquês de Maricá: "quando os bons capitulam com os maus, sancionam a própria ruína". 5 Seu objetivo era atacar a política dos praieiros e isso foi feito eficazmente. ${ }^{6} \mathrm{Em} 1849$, Figueiredo retornou ao cargo de professor no referido Liceu, depois do término da revolução. Teve participação intensa na imprensa pernambucana, ao lado dos conservadores ou guabirus e contra os liberais praieiros. Foi um porta-voz das reivindicações sociais em Pernambuco, apesar de protegido pelo Conde da Boa Vista, um guabiru. É responsável pela tradução para o português e divulgação entre nós do Curso de História da Filosofia (1843-5) de Cousin.7 A qualidade da tradução e sua atuação ousada na imprensa levaram seus inimigos praieiros a ver nele nada mais do que um mulato pernóstico e bajulador dos poderosos, atribuindo-lhe o apelido racista e pejorativo de ridículo Cousin Fusco. ${ }^{8}$ Figueiredo foi redator chefe da já mencionada revista $O$ Progresso, de 1846 a 1848. Nessa época, envolveu-se em um debate com Nascimento Feitosa, que, sob o pseudônimo de Discípulo da Filosofia, criticou um artigo seu sobre a Certeza humana, publicado no primeiro número da revista. Em 1852, envolveu-se em outro debate, desta vez sobre o socialismo, com o conselheiro Pedro Autran da Matta Albuquerque. Seus artigos foram publicados no Diário de Pernambuco e no jornal $A$ Imprensa, enquanto os do conselheiro saíram no jornal União (SACRAMENTO BLAKE, 1900, p. 276-7). Colaborou no Diário de Pernambuco de 1855 a 1859, tendo ali escrito, sob o pseudônimo de Abdalah-el-Kratif e sob o título A Carteira, 160 folhetins voltados para a história, a filosofia, as letras, as artes, a política e a crítica literária.

\footnotetext{
${ }^{4}$ Naquela época, a política pernambucana era dominada pelas famílias Cavalcanti, do partido liberal, e Rego Barros, do partido conservador. Essas famílias mantinham acordos políticos que lhes permitiam desfrutar das vantagens do poder qualquer que fosse o partido governante. Contra essa situação rebelaram-se alguns integrantes do partido liberal, que fundaram o Partido Nacional de Pernambuco ou Partido da Praia. Foi esse último que desencadeou a chamada Revolução Praieira, iniciada em novembro de 1848.

${ }^{5}$ Ver (MARICÁ, 2011, máxima 820).

${ }^{6}$ As informações sobre o jornal O parlamentar foram extraídas de (NASCIMENTO, 1969, p. 289).

7 Ver (COUSIN, 1843-45). Não tivemos acesso a essa obra.

${ }^{8}$ Nos dias de hoje, o apelido seria algo como Cousin Mulato, ou Cousin Escurinho.
} 
Nessa época, depois de muita luta contra os obstáculos criados por seus inimigos, conseguiu apoio financeiro para viajar à Europa com o objetivo de aprimorar seus conhecimentos. Mas ficou doente e teve de desistir do projeto. Faleceu em 22/08/1859. Parece que a disciplina excessiva de estudos foi uma das causas de sua morte prematura, de congestão cerebral, aos 45 anos de idade.

Figueiredo não foi um autor de obras filosóficas de caráter mais sistemático, como no caso de Gonçalves de Magalhães ou de Pereira Barreto. Além disso, ele não tinha título acadêmico. Mesmo assim, possuía cultura e formação suficientes para contribuir inicialmente na divulgação das ideias de Cousin, através da tradução mencionada, e, depois disso, na divulgação de suas próprias concepções, que incluíam a defesa de ideias socialistas e princípios cristãos, através de seus trabalhos na imprensa pernambucana. Por esses motivos, Figueiredo merece o já mencionado lugar de destaque na filosofia brasileira do s. XIX.

\section{A teoria do conhecimento de Figueiredo}

\section{A questão dos textos relevantes}

Antes de discutir qualquer uma das ideias filosóficas de Figueiredo, temos de reiterar aqui que ele não é autor de obra sistemática, tendo escrito apenas uma série de textos esparsos sobre diversos assuntos. Isso não quer dizer que ele não tivesse um sistema de ideias articulado de alguma forma, mas sim que a compreensão de seu pensamento envolve o trabalho de buscar nos seus textos os elementos teóricos mais relevantes para organizá-los sob a forma de uma exposição teórica consistente. Esse procedimento será adotado por nós na apresentação de sua teoria do conhecimento, que está relacionada aos seguintes textos: o artigo Certeza Humana, publicado em $O$ Progresso, no 1, o artigo Processos Lógicos do Espírito Humano, publicado em $O$ Progresso, n², além de seu debate com o mencionado Discípulo da Filosofia, debate esse que ficou registrado sob a forma de três artigos intitulados Primeira, Segunda e Terceira Resposta ao Discípulo da Filosofia, publicados em O Progresso, a primeira delas no no 3, e as duas restantes no $n^{\circ} 4$. O mais importante desses artigos é sem dúvida Certeza Humana, em que ele se afasta da teoria cousiniana do conhecimento e oferece uma alternativa própria, tendo com isso desencadeado uma acalorada disputa com o Discípulo da Filosofia. $\mathrm{O}$ artigo sobre Processos Lógicos do Espírito Humano trata sobretudo da questão do raciocínio, mas introduz alguns esclarecimentos com relação à posição assumida no artigo anterior. ${ }^{9}$ As respostas ao Discípulo da Filosofia, principalmente a segunda e a terceira, servem apenas para esclarecer alguns pontos da doutrina figueirediana. Ora, temos de convir que essa produção é muito limitada e oferece muito pouco para esclarecermos a doutrina de Figueiredo em uma questão tão complexa como a teoria do conhecimento. O máximo que podemos fazer aqui é recolher as informações esparsas nesses textos e tentar elaborar uma interpretação provável de seu pensamento nesse domínio. De qualquer modo, sobretudo por motivos de espaço, iremos basear nossa apresentação nos artigos Certeza Humana e Processos Lógicos do Espírito Humano, deixando de lado as respostas ao Discípulo da Filosofia. Embora a nossa exposição fique incompleta por causa disso,

\footnotetext{
${ }^{9}$ No no 2 de O Progresso, esse artigo tem o título apenas de Processos Lógicos. Ao final do Tomo ll da revista, porém, na edição promovida por Amaro Quintas, há um Índice das matérias conteúdas nos dois primeiros tomos do Progresso, em que o título do artigo aparece como Processos Lógicos do Espírito Humano (O PROGRESSO, 1950, p. 767). Em nossa exposição, adotaremos o título mais longo.
} 
acreditamos que a compreensão do essencial da teoria figueirediana do conhecimento por parte do leitor não será prejudicada.

\section{O artigo Certeza Humana}

\section{9. parte: to be or not to be!}

Esse artigo se divide em três partes. Na primeira delas, cujo título, que também serve de mote, é To be or not to be!, Figueiredo associa a indecisão do personagem Hamlet à questão da certeza, anunciando assim a dificuldade em resolvê-la. De acordo com ele, a questão de saber se o ser humano pode chegar à verdade recebeu diversas soluções, mas nenhuma delas foi capaz de persuadir a humanidade. Locke afirma que a causa disso está no fato de que as discussões filosóficas são meras disputas de palavras ou logomaquias. Figueiredo concorda com isso e generaliza a explicação lockiana, propondo que os filósofos essencialmente possuem a mesma opinião e que as discussões entre eles cessariam se houvesse uma língua cujos termos tivessem significação precisa, assim como acontece na matemática. Nessa perspectiva, a questão da certeza se torna confusa em virtude do sentido vago dos termos usados para justificá-la e constitui o ponto de divergência de todos os sistemas: os céticos negam a sua possibilidade; os dogmáticos - idealistas e sensualistas - admitem a certeza em certos domínios e em outros, não (FIGUEIREDO, 1950a, p. 13-4). Como podemos ver, a frase to be or not to be, que serve de mote a essa parte do artigo, expressa o estado de dúvida decorrente do conflito.

\section{$2^{a}$. parte: errare humanum est}

Na segunda parte do artigo, intitulada Errare humanum est, Figueiredo faz um apanhado das principais soluções filosóficas oferecidas ao problema da certeza, mostrando os erros das mesmas, antes de apresentar sua posição pessoal sobre o assunto. Ele analisa inicialmente a solução cética, na versão do ceticismo transcendente de Jouffroy. ${ }^{10} \mathrm{O}$ argumento desse último parte da seguinte situação: ele vê uma árvore e afirma que ela existe. Essa afirmação seria uma verdade humana. Mas isso nos leva à seguinte disjunção baseada no princípio de contradição: ou é absolutamente verdadeiro que a árvore existe ou é absolutamente verdadeiro que a árvore não existe. Nos dois casos, teríamos uma verdade absoluta. Logo, existe uma verdade absoluta. Ora, a justificativa da existência de uma verdade absoluta só pode ser feita pela inteligência humana. Mas nesse caso a inteligência humana estaria circularmente pressupondo a sua própria legitimidade para efetuar tal justificativa. Diante disso, Jouffroy conclui pela validade do ceticismo. E seus seguidores chamaram de ceticismo transcendente a essa solução apriorística do problema do conhecimento. Contra essa posição, Figueiredo argumenta que o próprio princípio de contradição utilizado para a conclusão da existência de uma verdade absoluta já é essencialmente humano e por isso mesmo subjetivo. A legitimidade da inteligência já está sendo pressuposta nessa operação. Desse modo, a afirmação da existência de uma verdade absoluta, antes mesmo da apresentação de sua justificativa, já pressupõe a legitimidade da inteligência. A verdade absoluta é, na realidade, uma verdade subjetiva e o ceticismo transcendente, um contrassenso (FIGUEIREDO, 1950a, p. 14-5).

\footnotetext{
${ }^{10} \mathrm{O}$ autor em questão é Théodore Jouffroy (1792-1842), ligado à escola eclética francesa.
} 
Depois de criticar o ceticismo, Figueiredo passa aos dogmáticos que, por sua vez, analisam a questão da certeza a partir da oposição entre multiplicidade e unidade, conforme preconiza Cousin. Os sensualistas absorvem a unidade na multiplicidade, o eu no não-eu; os idealistas absorvem a multiplicidade na unidade, o não-eu no eu. Na sequência, Figueiredo faz um apanhado das teses comuns aos materialistas, sensualistas, idealistas e spinozistas. Os pensadores por ele considerados incluem os pré-socráticos da Escola Jônica, os Eleatas, Spinoza, Locke, Condillac, Berkeley, Hume, Kant e Fichte. Não trataremos de todos eles aqui em detalhe. O próprio Figueiredo também não faz isso. O seu argumento central se baseia na análise que Cousin faz do conhecimento humano, dividindo-o em dois polos, a unidade e a multiplicidade. A partir daí, Figueiredo afirma que os sistemas dogmáticos enfatizam a existência de um desses termos em detrimento do outro. Assim, os sensualistas absorvem o eu no não-eu, a unidade na multiplicidade, enquanto os idealistas percorrem o caminho inverso, absorvendo o não-eu no eu, a multiplicidade na unidade. Quanto ao método, os materialistas jônios, os espiritualistas eleáticos e Spinoza procedem sinteticamente. ${ }^{11}$ Já os sensualistas e idealistas modernos procedem de maneira predominantemente analítica. Por razões de espaço, omitiremos aqui os detalhes da exposição e da crítica que Figueiredo faz desses diversos sistemas. Restringir-nosemos às suas conclusões, que são as seguintes. Figueiredo procura mostrar que os materialistas e os sensualistas, pelo fato de absorverem a unidade na multiplicidade, são levados a negar a própria multiplicidade assumida como ponto de partida. Isso é assim porque a sua teoria da origem das ideias não reconhece, na análise do fenômeno da formação das mesmas, a necessidade de um sujeito com suas leis de organização. Os idealistas, por sua vez, pelo fato de absorverem a multiplicidade na unidade, são levados a negar a multiplicidade, tendo de admitir apenas a existência do sujeito ilimitado, infinito e imóvel. Ambos os sistemas terminam pela negação da multiplicidade e apontam em direção ao ceticismo, criando um grande embaraço para a filosofia (FIGUEIREDO, 1950a, p. 15-9).

Nesse momento, surge a solução de Cousin, para quem as duas escolas dogmáticas adotariam pontos de vista verdadeiros, de tal modo que a união dos mesmos levaria à verdadeira filosofia. Mas, para Figueiredo, o próprio Cousin cai também no dogmatismo, ao dividir as ideias em dois grupos: necessárias/absolutas e contingentes/relativas. O primeiro grupo corresponderia ao idealismo e o segundo, ao sensualismo. Para Figueiredo, essa divisão corresponde a uma versão levemente modificada do sistema de Kant, que leva ao idealismo subjetivo de Fichte. Para evitar que o não-eu seja absorvido pela subjetividade do eu, Cousin propõe a teoria das apercepções puras. ${ }^{12}$ De acordo com Figueiredo, essa teoria afirma que o pensamento humano possui dois momentos, o da espontaneidade e o da reflexão. Pela primeira, o ser humano acessa, ainda que de maneira confusa, o finito (eu), o infinito (não-eu) e sua relação. Pela reflexão, essas ideias são esclarecidas e organizadas, mas nada é acrescentado ao que veio da

\footnotetext{
11 Spinoza foi incluído nesse grupo porque Figueiredo parece estar seguindo a visão cousiniana da história da filosofia. Nesta, Descartes, Spinoza e Malebranche representam a escola idealista da primeira época da filosofia moderna (s. XVII). A segunda época da filosofia moderna ocorre no s. XVIII (COUSIN, 1829, p. 437-68).

12 Em sua exposição, Figueiredo está supondo que o leitor conhece a teoria cousiniana das apercepções puras, oferecendo uma apresentação bastante resumida da mesma. Para auxiliar na compreensão dessa teoria, acrescentamos que, de acordo com Cousin, o ser humano apreende o absoluto numa sequência de momentos distintos. No primeiro, o absoluto é apreendido como ideia sob a forma de uma apercepção pura. Essa última é ao mesmo tempo luminosa e obscura, constituindo o momento mais puro que o ser humano pode alcançar na apreensão do absoluto. Temos aqui, como podemos ver, uma intuição direta da divindade por parte do ser humano, numa forma de ontologismo. No segundo momento, a apercepção pura é obscurecida pela reflexão, o que lhe permite tornar-se clara para o intelecto humano. Figueiredo não menciona isso em seu artigo, mas Cousin reconhece ainda a existência de mais dois momentos. No terceiro, a apercepção pura passa da apercepção refletida do segundo momento para a concepção necessária. Por fim, no quarto momento, a apercepção pura se torna crença, deixando de ser reflexiva e adquirindo uma falsa espontaneidade de aplicação.
} 
espontaneidade. Em virtude disso, as ideias de finito, infinito e sua relação são impessoais e independentes do eu. Como tais ideias constituem a razão humana, Cousin conclui, contra Kant e sua escola, que a razão humana é independente do eu e corresponde à substância verdadeira, à essência absoluta. Para Figueiredo, o argumento de Cousin mostra que a razão humana pode ser considerada independente do eu enquanto eu voluntário, mas não pode ser subtraída da espontaneidade desse mesmo eu. Esse último surge, assim, como um dos pontos de vista abstratos do próprio eu. Por esse motivo, Cousin provavelmente consideraria sua solução como um erro de juventude (FIGUEIREDO, 1950a, p. 20-1). Daí a expressão errare humanum est, que constitui o mote da segunda parte.

\section{3a. parte: numeri regunt mundum}

Na terceira e última parte do artigo, com o título que, como no caso anterior, também serve de mote - Numeri regunt mundum (Pitágoras) - Figueiredo apresenta finalmente a sua resposta à questão da certeza, iniciada pela oposição entre jônios e eleatas e continuada pela oposição entre sensualistas e idealistas. Com sua abordagem, ele pretende superar o ceticismo para o qual ambos os sistemas apontam. Em coerência com o que foi colocado na primeira parte do artigo, Figueiredo pensa que a questão da certeza ainda não foi resolvida porque foi mal colocada. Ele argumenta que todo raciocínio possui uma base que não pode ser provada sem cairmos em paralogismo. E, partindo dessa base, só conseguiremos extrair dela o que já estiver ali implicitamente contido. Afinal de contas, todos os raciocínios estão submetidos à seguinte regra eterna da lógica: a primeira das premissas contém a conclusão e a segunda mostra que ela ali está contida (prima proemissarum conclusionem contineat et altera contentam demonstret). Ora, os filósofos têm estabelecido, como ponto de partida de suas doutrinas, os resultados a que chegaram. Eles teriam deixado de lado tal ponto de partida se tivessem uma noção clara das consequências implícitas que o mesmo encerra (FIGUEIREDO, 1950a, p. 21-2).

Em oposição a isso, Figueiredo afirma que todo conhecimento humano é necessariamente subjetivo, uma vez que se reduz a uma ideia que nada mais é do que o resultado da percepção de uma relação. No ato de conhecimento, o homem é sujeito e a relação é o objeto. A noção de verdade absoluta é equivocada, mas isso não significa que a verdade humana não seja garantida por toda a certeza possível. O sujeito é o elemento ineliminável da própria ideia de certeza e a ideia de verdade possui origem puramente humana. Assim, não faz sentido perguntar se as ideias correspondem a alguma realidade exterior, pois a própria ideia de realidade é um produto humano. A crença na existência do mundo exterior é tão válida quanto a crença na nossa própria existência. Com efeito, a crença em nossa própria existência é o resultado de um fenômeno em cuja composição entram, de um lado, a nossa inteligência com sua organização específica, e, de outro, uma sucessão de relações entre nós e algo exterior a nós. A base da certeza humana é simultaneamente objetiva e subjetiva, o que explica os resultados legítimos obtidos tanto pelos sensualistas como pelos idealistas. A disputa entre ambos não passa de uma questão de palavras, conforme mencionado anteriormente. Essa logomaquia resulta do fato de se privilegiar apenas um dos elementos componentes da certeza humana em detrimento do outro (FIGUEIREDO, 1950a, p. 22-3).

Em síntese, o espírito humano só percebe relações. Nossa existência é dada a partir de relações entre nós e algo exterior a nós. A existência de algo exterior a nós é dada a partir de relações entre esse algo exterior e nós. A noção de existência supõe dois termos e uma série de relações entre eles, de tal modo que um deles não pode ser suprimido sem eliminação das relações, com a resultante negação da existência. Nesse ponto, Figueiredo apresenta a seguinte 
equação matemática para ilustrar sua argumentação: seja $\mathrm{m} / \mathrm{nm}=e$; se fizermos $n m=0$, então $m / 0=\infty$, ou seja, o nada ou o infinito que perpassa tudo como negação do finito e seus atributos, como a duração, o limite, etc. O significado dessa equação é obscuro e será discutido mais adiante. Figueiredo continua a argumentação alegando que a relação da existência ao nada, do finito ao infinito, do alfa ao ômega, constitui o princípio e o fim de todas as coisas. Esses pares envolvem conceitos correlativos, que se supõem mutuamente, de tal modo que a razão humana pode exclamar, como o apóstolo Paulo, que in Deo vivimus, movemur et sumus (em Deus vivemos, nos movemos e existimos) (FIGUEIREDO, 1950a, p. 23-4).

Em virtude da importância dessa frase latina para a nossa discussão, explicaremos a seguir, num breve excurso, o contexto de seu aparecimento e seu significado. Sabemos que, no ano de $41 \mathrm{~d}$. C., esse apóstolo visitou Atenas, onde fez um discurso que foi registrado por Lucas, nos Atos dos Apóstolos (Atos, 17: 22-31). Em sua fala, Paulo procurou mostrar sua familiaridade com os escritos e as crenças dos gregos, utilizando-os para poder convertê-los ao cristianismo. No decorrer da sua argumentação, Paulo afirma que Deus dá a nós todos a vida, a respiração e tudo mais. Deus não está longe de nenhum de nós, pois "Nele vivemos e nos movemos e existimos" (Atos, 17, 28). Essa frase foi atribuída a Paulo por muito tempo, só que, mais recentemente, descobriu-se que não é dele, e sim de Epimênides, autor de um conhecido poema da época, intitulado Cretica, que foi escrito entre 600 e 700 a. C. ${ }^{13}$ Num dos versos desse poema, o personagem Minos, filho de Zeus, se refere a seu pai, dizendo o seguinte:

Eles fabricaram um túmulo para ti, ó santo e altíssimo [Zeus],

Esses cretenses, sempre mentirosos, bestas malvadas, glutões preguiçosos;

Mas Tu não estás morto, pela eternidade Tu vives e te sustentas,

Pois em Ti vivemos, nos movemos e existimos. (EPIMÊNIDES, apud LAWLOR, 1916, p. 180. Grifos nossos)

A importância filosófica do último verso da citação acima, da qual Paulo se apropriou, está em suas consequências metafísicas. Esse verso possui um viés panteísta e foi visto por alguns autores como uma das fontes do panteísmo cristão. Essa constatação tem algum fundamento, pois Epimênides tinha ligações com o orfismo e essa antiga religião também apresenta traços de panteísmo. ${ }^{14}$ Mas dificilmente o apóstolo Paulo poderia ser considerado um panteísta. $\mathrm{Na}$ verdade, a maior parte das versões do cristianismo possui um caráter panenteístico. Nelas, Deus cria continuamente o mundo e está presente nele o tempo todo, embora não se confunda com sua criação, transcendendo-a. Paulo parece compartilhar essa tendência, como podemos

\footnotetext{
${ }^{13}$ Epimênides (circa s. VI a.C.?) foi um adivinho cretense, autor de várias obras poéticas e místicas, dentre as quais se destaca o poema Cretica. Parece que acreditava em teorias religiosas próximas do orfismo. Platão e Aristóteles afirmam que ele realizou rituais purificadores em Atenas. Tais rituais levaram à construção de um altar ao "deus desconhecido", também mencionado por Paulo no início de seu discurso aos atenienses (Atos, 17: 23). As lendas a seu respeito dizem que ele dormiu miraculosamente por 57 anos numa caverna consagrada a Zeus, tendo adquirido seus poderes de profecia ao acordar, e que ele morreu numa idade muito avançada, com 157 ou 299 anos. O fato de ser cretense e ter afirmado serem todos os cretenses mentirosos em seu poema, levou o apóstolo Tito a perceber o conhecido paradoxo do mentiroso (Tito, 1: 12). Uma das versões desse paradoxo é a seguinte: Epimênides, que nasceu em Creta, afirmou que todos os cretenses são mentirosos; ele falou a verdade ou mentiu? Se ele mentiu, então falou a verdade, já que todos os cretenses são mentirosos. Se ele falou a verdade, então mentiu, uma vez que todos os cretenses são mentirosos (formulação nossa). A hipótese de que Paulo citou Epimênides nós extraímos de: (LAWLOR, 1916, p. 180-93). O discurso de Paulo envolve também uma citação do poeta Arato, segundo a qual "somos seus filhos [de Deus]", que não levaremos em conta aqui por motivo de espaço.

${ }^{14}$ De maneira extremamente resumida podemos dizer que, segundo o orfismo, o Primeiro Nascido ou Phanes surgiu de um Ovo e que Zeus o engoliu. Com isso, tudo o que existia estava em seu ventre e todas as coisas foram recriadas: o céu, o mar, a terra e todos os deuses imortais. Tudo o que existia e tudo o que existirá está mesclado no ventre de Zeus. Para maiores detalhes, ver (ORPHIC RHAPSODIC THEOGONY, THE RISE OF THE SIX KINGS). Disponível em <http://www.hellenicgods.org/orphicrhapsodies-----24>. Ver também (ORPHIC FRAGMENT 165 - OTTO KERN). Disponível em: <http://www.hellenicgods.org/orphicfragment-165---otto-kern>. Acessos em: abr. 2020.
} 
inferir de outro de seus ditos, segundo o qual "por Ele [Deus] todas as coisas foram criadas: as coisas no céu e na terra, visíveis e invisíveis, [...]; todas as coisas foram criadas através Dele e por Ele. Ele está antes de todas as coisas, e Nele todas as coisas se ligam" (COLOSSENSES, 1: 16-17).

Retornando à exposição das doutrinas contidas no artigo Certeza Humana, resta-nos fazer uma última observação. A expressão latina numeri regunt mundum, que encabeça a terceira parte do artigo, tem uma relação menos clara com o conteúdo tratado, demandando maiores esclarecimentos. Abordaremos esse ponto mais adiante.

\section{O artigo Processos lógicos do espírito humano}

Esse artigo foi publicado em $O$ Progresso, $n^{\circ} 2$. Nele, Figueiredo utiliza como mote uma frase de Bacon, segundo a qual a natureza afeta nosso intelecto diretamente, ao passo que o homem a exibe de maneira indireta: percuti natura intellectum nostrum radio indirecto [...]. Ipse vero homo semetipsi monstratur et exhibetur radio reflexo. ${ }^{15}$ Nesse texto, Figueiredo pretende mostrar como pode o ser humano chegar à certeza quando afirma alguma coisa. Isso ocorre através da inteligência, que também pode nos levar a muitos erros. Figueiredo se pergunta de onde nascem esses erros e como podemos evitá-los. Quais seriam os processos a serem empregados para chegar à verdade? De acordo com ele, essas questões são respondidas pela lógica, que ele define como "a ciência que tem por alvo investigar e estabelecer os processos que o homem deve empregar para chegar à verdade". Essa definição, por si só, já mostra a importância da lógica, que constitui o antecedente necessário de qualquer ciência. São tarefas da lógica: i) o estudo dos meios disponíveis para chegarmos à verdade; ii) o emprego desses meios ou método para chegarmos à verdade. No presente artigo, Figueiredo se dispõe a estudar o item "i", prometendo tratar do item "ii" em um outro artigo (FIGUEIREDO, 1950b, p. 83-4).

No que segue, Figueiredo faz uma apresentação dos principais conceitos ligados ao item "i". Um fato importante a ser destacado aqui é que ele se afasta da lógica aristotélica tradicional, embora se baseie na teoria do silogismo. Figueiredo começa reiterando a tese defendida no artigo anterior, segundo a qual todo conhecimento resulta da percepção de uma relação. $\mathrm{E}$ acrescenta que tal percepção constitui um juízo, que toma a forma exterior de uma proposição, a qual se compõe de sujeito, verbo e predicado (FIGUEIREDO, 1950b, p. 84). Nesse ponto, era de se esperar que ele desenvolvesse um estudo dos termos constitutivos da proposição, no espírito da lógica aristotélica. Ao invés disso, ele passa diretamente à doutrina do juízo, deixando de informar não apenas qual a importância que confere aos elementos constitutivos da proposição, mas também se admite uma distinção entre o conceito e o termo, do mesmo modo que admite uma distinção entre o juízo e a proposição.

Dando seguimento à sua exposição, Figueiredo afirma que, apesar de possuírem todos a mesma forma, os juízos diferem quanto ao caminho percorrido pelo espírito para chegar a eles. P. ex., recebemos uma impressão através dos sentidos e nossa inteligência formula imedia-

\footnotetext{
15 No texto que consultamos, a passagem completa de Bacon a esse respeito é a seguinte: "Philosophiae autem objectum triplex, Deus, Natura, Homo; et triplex itidem radius rerum; natura enim percutit intellectum radio directo, Deus autem, propter medium inaequale (creaturas scilicet), radio refracto; homo vero, sibi ibsi monstratus e exhibitus, radio reflexo" (BACON, 1857, p. 540). Uma tradução possível seria: "A filosofia tem um tríplice objeto, Deus, a Natureza e o Homem; e do mesmo modo é tríplice o raio deles [desses objetos]; a natureza influencia o intelecto pelo raio direto; Deus, por causa do meio desigual (ou seja, as criaturas) o influencia através de raios refratados; o homem se mostra e se exibe a si mesmo pelo raio reflexo". Figueiredo provavelmente tomou conhecimento dessa frase de Bacon através do Curso de História da Filosofia Moderna, de Cousin, que cita e comenta a mesma em nota de rodapé (COUSIN, 1847, p. 238, rodapé). As citações de Bacon por Cousin e Figueiredo, além de não indicarem de onde foram extraídas, não correspondem exatamente ao texto que consultamos.
} 
tamente um juízo a esse respeito: essa pedra é dura. Mas nossa inteligência também pode chegar a um juízo só depois de ter formulado uma série de outros, como, p. ex., no seguinte: uma quantidade qualquer dividida por zero torna-se infinitamente grande $(A / O=\infty)$. Os juízos do primeiro tipo são imediatos, filhos da espontaneidade, e os do segundo tipo, mediatos, filhos da reflexão. A certeza dos juízos mediatos depende inteiramente da certeza dos juízos imediatos dos quais são extraídos por meio do raciocínio (FIGUEIREDO, 1950b, p. 84-5). Figueiredo sintetiza as definições desses dois tipos de juízos como segue:

[...] há duas sortes de juízos bem distintos, não quanto à forma, mas quanto ao caminho que até eles nos conduz: $1^{\circ}$, aqueles que chamaremos imediatos, que são produzidos instantaneamente pelo espírito, quando os sentidos Ihe transmitem uma impressão recebida, donde resulta para ele a percepção de uma relação; $2^{\circ}$, aqueles que chamaremos mediatos, que são juízos que a inteligência só faz em virtude de outros juízos, de que eles, por assim, dizer, são consequências e de que ela os extrai por um processo particular (FIGUEIREDO, 1950b, p. 84-5).

Isso significa que os juízos mediatos apresentam maior probabilidade de erro do que os juízos imediatos. Nos dois casos, porém, para sair do eu e ser traduzido exteriormente, o juízo tem de assumir uma forma adequada através de uma língua. Acontece que, para Figueiredo, ainda não existia uma língua verdadeiramente filosófica, em que as palavras estivessem perfeitamente definidas, permitindo que os juízos fossem revestidos de uma forma correta. Em virtude disso, um juízo verdadeiro poderia ser formulado de maneira a parecer falso, produzindo as intermináveis discussões filosóficas que por 4000 anos tinham contribuído para que os interlocutores não se entendessem (FIGUEIREDO, 1950b, p. 85-6).

Quanto aos fatores que podem levar a erros nos dois tipos de juízos, Figueiredo argumenta que os juízos imediatos podem resultar falsos em virtude de dois fatores: a) a inexatidão na transmissão da impressão à inteligência; b) a imprecisão da língua usada para formular o juízo. Esse último fator constitui ocasião para Figueiredo reafirmar a tese lockiana de que as disputas filosóficas são logomaquias. Os juízos mediatos, que dependem do raciocínio para serem formulados, podem resultar falsos em virtude de dois outros fatores: a) o erro decorrente da realização de uma inferência não-válida; b) a falha da memória ao recuperar algum juízo imediato que serve de base à inferência (FIGUEIREDO, 1950b, p. 86-7).

Figueiredo passa nesse ponto para uma apresentação resumida da teoria do silogismo, mas com a ressalva de que esse instrumento lógico já era conhecido e usado muito tempo antes de Aristóteles. Figueiredo usa uma terminologia parcialmente diferente aqui, adotando o nome de proposição mãe para a premissa maior, proposição intermédia, para a premissa menor, e proposição filha, para a conclusão. Ele reconhece, sem maiores explicações, que o silogismo se compõe de três termos, o maior, o médio e o menor, mas se concentra nas relações lógicas entre as proposições do silogismo. Aqui, ele repete os principais aspectos da teoria aristotélico-escolástica do silogismo, incluindo a quádrupla classificação das proposições - A, E, I , O - e as noções de figuras e modos. Mas as oito regras tradicionais do silogismo não são incluídas na exposição, que reduz todas a uma só, já citada no artigo Certeza Humana: prima proemissarum conclusionem contineat et altera contentam demonstret. Figueiredo apresenta a seguir uma lista de oito raciocínios falsos ou sofismas, cuja sistematização ele atribui a Aristóteles. Essa lista inclui, p. ex., a ignorância do assunto, a petição de princípio, a ambiguidade, etc. (FIGUEIREDO, 1950b, p. 87-91).

A teoria do raciocínio indutivo também é resumidamente apresentada. Os dois tipos de indução - por enumeração completa e por enumeração incompleta - são considerados (FIGUEIREDO, 1950b, p. 91). 
Ao final, Figueiredo conclui que a certeza humana possui legitimidade e se baseia em ideias, que são traduzidas sob a forma de juízos. Todo juízo é o resultado da percepção de uma relação por parte do eu. Todos os erros decorrem ou da incerteza dos dados que servem de base aos juízos, ou da imperfeição da linguagem usada para exprimir esses juízos, ou do mau uso da faculdade de raciocinar. Nesse ponto, Figueiredo deixa a questão do método, mencionada no início do texto, como um assunto a ser discutido em artigo posterior (FIGUEIREDO, 1950b, p. 91-2). Tal artigo, porém, não foi publicado e provavelmente não foi escrito. Talvez tivesse algo a ver com o artigo Estado atual das ideias filosóficas, prometido na notícia de 23 de maio de 1846, no Diário de Pernambuco, sobre a criação de O Progresso, mas infelizmente não publicado na revista. Orsoni vê nesse fato uma inconsequência surpreendente, uma vez que a trilogia prometida de artigos estava destinada a explicar as bases filosóficas do programa da revista $O$ Progresso, tal como expressa na declaração de princípios publicada no seu n ${ }^{\circ} 1$ (ORSONI, 2013, p. 39).

\section{Nossa interpretação da teoria do conhecimento de Figueiredo}

Embora tenhamos apresentado acima as ideias de Figueiredo tais como se acham expressas nos dois artigos mencionados, muitos pontos estão a demandar maiores esclarecimentos, os quais iremos oferecer na presente seção. ${ }^{16}$ Pela análise dos textos apresentados acima, podemos constatar que, em Certeza Humana, Figueiredo revelou maior preocupação com as ideias, que ele identifica a juízos, do que com os termos constituintes das proposições que expressam os mesmos, aos quais ele fez poucas referências. De qualquer modo, sua tese principal é a de que todo conhecimento humano é subjetivo e corresponde a uma ideia que constitui a percepção duma relação. $\mathrm{O}$ ato de conhecer envolve um sujeito, que é o próprio ser humano, e um objeto, que é a relação por ele percebida. Nessa perspectiva, a impressão sensorial é transmitida ao intelecto, que recorre à linguagem para formular a proposição correspondente. Em outras palavras, o juízo está inicialmente contido no eu, sob a forma de ideia, e depois é traduzido exteriormente sob a forma de uma proposição. Daí o apelo figueirediano ao dito de Bacon, para quem a natureza afeta nosso intelecto diretamente, ao passo que o ser humano a exibe de maneira indireta. Daí também a afirmação figueirediana de que a certeza humana se baseia em ideias ou juízos, que são transmitidos sob a forma de proposições. A terminologia de Figueiredo não é muito clara, mas, depois de uma leitura cuidadosa, constatamos que ela permite fazermos essas distinções.

Em Processos Lógicos do Espírito Humano, Figueiredo afirma que os juízos podem ser de dois tipos: os imediatos, que são produzidos instantaneamente pelo espírito quando os sentidos Ihe transmitem uma impressão, expressando assim diretamente uma relação percebida, e os mediatos, que são produzidos pelo espírito a partir de outros juízos, dos quais eles constituem consequências. Os juízos imediatos são filhos da espontaneidade, ao passo que os juízos mediatos são filhos da reflexão. Isso significa que, para Figueiredo, existem duas fontes para o nosso conhecimento: a espontaneidade e a reflexão. A primeira permite à nossa inteligência formular espontaneamente os juízos imediatos e a segunda permite à nossa inteligência formular reflexivamente os juízos mediatos. Não há espaço aqui para apercepção pura

\footnotetext{
${ }^{16}$ A partir desse ponto, não iremos apresentar as localizações das doutrinas que estivermos explicando, pois isso já foi feito na exposição dos conteúdos dos artigos Certeza Humana e Processos Lógicos do Espírito Humano.
} 
do Absoluto. Por esse motivo, a correspondente doutrina cousiniana foi rejeitada por Figueiredo em Certeza Humana.

Ainda em Processos Lógicos do Espírito Humano, Figueiredo retoma o assunto da certeza, mas agora perguntando como pode o ser humano chegar a ela. Aqui, ele complementa algumas das ideias do artigo anterior, tornando mais clara a sua posição em teoria do conhecimento. $\mathrm{O}$ aspecto importante a ser destacado no artigo é a retomada da divisão dos juízos em imediatos e mediatos, em que os primeiros dependem da espontaneidade e os últimos, da reflexão, a qual é realizada através do raciocínio silogístico. E não podemos esquecer que Figueiredo reconhece ser esse tipo de raciocínio essencialmente circular, de tal modo que não podemos provar a premissa maior sem cair em paralogismo. Partindo dessa premissa, só poderemos concluir o que já estiver nela implicitamente contido.

Se nossa interpretação estiver correta, então torna-se compreensível a ênfase de Figueiredo no estudo dos juízos enquanto equivalentes às nossas ideias tais como ele as entende, bem como sua defesa da necessidade duma linguagem adequada, cujas palavras tenham sido definidas com precisão a fim de construir proposições capazes de expressar corretamente os nossos juízos, sejam eles imediatos ou mediatos. Torna-se compreensível também seu apelo ao conceito lockiano de logomaquia para explicar as controvérsias filosóficas, as quais são geradas mais pela imprecisão da linguagem do que por qualquer outra coisa.

Isso posto, temos ainda a considerar a importante noção figueirediana de existência. A esse respeito, nosso autor afirma em Certeza Humana que o nosso espírito só percebe relações, de tal modo que apenas elas manifestam a existência. É verdade que o espírito humano pode, em virtude da sua faculdade de abstrair, considerar isoladamente ou a si mesmo ou a um objeto qualquer, ou ao mundo exterior a si, mas não pode aplicar legitimamente a essas abstrações a noção de existência. Essas afirmações levantam um problema que não foi devidamente esclarecido por Figueiredo: se uma ideia é a percepção duma relação envolvendo dois termos, qual é o estatuto da abstração produzida pela nossa faculdade de abstrair, uma vez que tal abstração se refere apenas a um dos termos dessa relação, ao qual isoladamente não podemos atribuir existência? Ela não pode ser uma ideia no sentido definido por Figueiredo, pois se refere a apenas um dos termos da relação. $E$, do mesmo modo que essa abstração existe em nossa mente, assim também o termo da relação ao qual ela se refere possui uma existência abstrata em nossa mente. Ora, parece-nos que essa existência abstrata só pode ocorrer sob a forma de um conceito. Vimos anteriormente que Figueiredo, em Processos Lógicos do Espírito Humano, não nos informa qual a importância que concedia aos elementos constitutivos da proposição nem se admite uma distinção entre o conceito e o termo. Mas seus textos permitem inferir que ele assume mais ou menos implicitamente a existência não só das ideias, mas também dessas pouco esclarecidas abstrações em nossa mente. À primeira vista, ele parece ter adotado uma posição nominalista. Mas a distinção mais ou menos explícita que ele faz entre juízo como entidade mental e proposição como entidade linguística que expressa o primeiro, bem como as distinções implícitas entre ideia ou juízo, envolvendo uma relação, e abstração, envolvendo a consideração isolada de um dos termos da relação, sugerem que o autor de Certeza Humana era partidário de alguma forma de conceptualismo, apesar da sua insistência na importância da linguagem e da ausência de uma doutrina do conceito em sua teoria do conhecimento. Essa nossa hipótese, porém, não vai além de uma conjetura provável, pois não há elementos nos poucos textos de nosso autor a respeito do assunto para nos fornecer uma resposta mais conclusiva.

Ainda com relação à noção de existência, Figueiredo acrescenta que a nossa crença no mundo exterior é tão válida quanto a crença na nossa própria existência. Essa última nos é dada 
como algo inseparável da preexistência de uma série de relações entre nós e alguma coisa que nos é exterior. E a crença no mundo exterior nos é dada do mesmo modo, como inseparável da preexistência de uma série de relações entre esse mundo exterior e alguma coisa que lhe é exterior, a saber, nós mesmos. Como podemos ver, a existência do eu e do mundo exterior é dada através da percepção das relações entre ambos, de tal modo que, embora possamos pensar abstratamente cada um dos elementos dessa relação isoladamente, a noção de existência é eliminada quando o outro elemento é eliminado. Desse modo, a crença no mundo exterior e na nossa própria existência resultam de um fenômeno que envolve, de um lado, a nossa inteligência enquanto dimensão subjetiva e, de outro, a sucessão de relações entre ela e exterior, enquanto dimensão objetiva.

Com base nessa perspectiva, Figueiredo estabelece, ao estilo de Cousin, pares de conceitos que se supõem mutuamente, tais como existência/nada, finito/infinito, alfa/ômega, etc. Isso significa, p. ex., que não podemos pensar a existência sem o nada, o finito sem o infinito, o alfa sem o ômega. E, embora não tenha sido explicitamente mencionado, o par Ser Perfeito/ser imperfeito ou Deus/criatura parece também envolver conceitos correlativos. É por isso que Figueiredo recorre ao apóstolo Paulo, dizendo que vivemos, nos movemos e somos em Deus. Em outras palavras, estamos em relação com Deus e nossa existência se encontra nessa mesma relação com Ele. Em linhas gerais, o argumento de Figueiredo sobre esse ponto repete, mutatis mutandis, de acordo com as conveniências teóricas do artigo sobre a Certeza humana, a dedução que faz Cousin do Absoluto ou Infinito (COUSIN, 1833, p. xxiv).

Para ilustrar essa sua posição, Figueiredo recorre à equação matemática já mencionada: em $m / n m=e$, se fizermos $n m=0$, então $m / 0=$ infinito, que perpassa tudo como negação do finito. O sentido dessa equação é difícil de estabelecer, dado que não há indicação do que significaria cada letra usada na mesma. Mesmo assim, tendo em vista o espírito da argumentação figueirediana que precedeu a introdução da equação, podemos elaborar uma conjetura a respeito. A fração $\mathrm{m} / \mathrm{nm}$ parece indicar dois termos correlativos, de tal modo que um, $\mathrm{nm}$, corresponderia à negação do outro, $m$. Estamos tomando $n m$ como abreviação de não- $m$. O símbolo $e$ do segundo membro da equação parece indicar a existência, correspondendo à relação entre os termos $m$ e $n m$. Nesse caso, a equação indicaria que a existência e não é atributo de $m$ nem de $n m$, mas o resultado da relação entre ambos. Desse modo, se fizermos o termo $\mathrm{nm}$ igual a zero, a fração $\mathrm{m} / 0$ tenderia ao infinito, já que seu denominador seria infinitamente pequeno. Ora, o infinito resultante seria equivalente ao nada, negando os atributos do finito, como a duração e a limitação espacial. Figueiredo não avança a argumentação em torno da equação, mas, como temos dois termos correlativos envolvidos e ele admite que a existência seria suprimida se eliminássemos qualquer um dos dois, façamos então $m=0$. Nesse caso, teríamos $0 / \mathrm{nm}=0$, ou seja, novamente estaríamos na presença do nada, mas agora não sob a forma da negação do finito e sim sob a forma da supressão do finito. Não sabemos o que Figueiredo quis significar com o símbolo m e seu correlativo nm: mente e não-mente? mundo e não-mundo? O certo é que e parece indicar a existência e a fração $\mathrm{m} / \mathrm{nm}$, os dois termos correlatos. Reconhecemos que nossa interpretação envolve muita especulação, mas acreditamos que ela expressa, na medida do possível, o espírito da posição de Figueiredo.

O apelo à equação acima parece justificar o apelo a Pitágoras e a presença da frase os números governam o mundo como mote da terceira parte de Certeza Humana. Todavia, Figueiredo faz ali uma obscura ligação entre os seguintes elementos: i) sua concepção dos termos correlatos obtidos a partir da categoria de relação; ii) o dito de Pitágoras sobre o fato de os números regerem o mundo, encabeçando a seção; e iii) a frase latina do apóstolo Paulo in Deo vivimus, movemur et sumus. Como explicar isso? 
Acreditamos ter encontrado a resposta para essa questão na maneira pela qual Leroux trabalha um tema semelhante em seu livro Da Humanidade (LEROUX, 1840). Ali, ele cita pelo menos três vezes a frase de Paulo na versão latina. Na primeira delas, ele afirma que Deus não está fora do mundo, porque o mundo não está fora de Deus: in Deo vivimus, et movemur, et sumus, como diz admiravelmente o apóstolo Paulo (LEROUX, 1840, p. 227). Na segunda, ele alega que, embora Deus tenha sido colocado bem longe da terra, Ele está por toda a parte. Ele está em nós em todos os momentos de nossa existência, porque não podemos viver sem Ele e Nele vivemos: in Deo vivimus, et movemur, et sumus, como diz Paulo (LEROUX, 1840, p. 232). Na terceira e última, que consideramos a mais importante, Leroux cita dessa vez todo o trecho relevante do discurso de Paulo aos atenienses, incluindo a frase latina (LEROUX, 1840. p. 452-3). E acrescenta uma comparação entre as ideias de Paulo e as de Apolônio. ${ }^{17}$ Leroux pensa que, assim como Paulo liga a imortalidade de ressurreição à natureza essencial de Deus e conclui, a partir da imanência de Deus em todas as criaturas, do mesmo modo Apolônio, para explicar a ressurreição eterna, mostra que toda modificação dos seres pertence ao Ser Universal, em Quem vivem o mundo e todas as criaturas, em Quem nós vivemos, nos movemos e existimos, como diz Paulo. Leroux alega que esse último, ao exortar os gregos a se converterem à nova religião cristã, procurou apoiar-se particularmente em Pitágoras e em suas concepções da unidade de Deus e da imanência de Deus no seio de todas as criaturas. Leroux recorre aqui ao Mártir Justino, para quem Pitágoras só ensinou sobre Deus aquilo que tinha aprendido no Egito, mas expôs suas ideias debaixo do véu misterioso dos símbolos. ${ }^{18}$ De acordo com Mártir Justino, quando Pitágoras afirma em sua teoria dos números que a unidade é o princípio de todas as coisas e a causa de todo bem, ele está entendendo essa unidade como o Ser Uno, ou Deus (LEROUX, 1840, p. 454-5). Leroux acrescenta aqui a citação de uma passagem atribuída a Pitágoras, feita na obra Exortação aos gregos, que ele considera ter sido escrita por Mártir Justino, mas que atualmente é atribuída a um autor anônimo, conhecido como Pseudo Justino. De qualquer modo, devido à sua importância para a discussão, a citação merece ser reproduzida:

Deus é um, não fora do mundo, como alguns imaginam, mas no mundo mesmo, vendo e ao mesmo tempo abarcando todas as criaturas e todas as criações ou gerações de seres, no círculo completo de suas existências simultâneas ou sucessivas. Deus é o moderador de todos os séculos, a causa e o operário, aquele que pode e aquele que age. Ele é o princípio

\footnotetext{
${ }^{17}$ Apolônio de Tiana (c. 15 - c. 100 d.C.) foi um filósofo neopitagórico grego nascido em Tiana, cidade localizada na província romana da Capadócia, na Anatólia. Foi contemporâneo de Jesus Cristo e teve sua biografia escrita pelo sofista Filóstrato, a pedido da imperatriz consorte Julia Domma, esposa de Septímio Severo e mãe dos futuros imperadores Geta e Caracala. Na biografia que escreveu, Filóstrato atribui a Apolônio poderes de percepção extrasensorial e relata sua viagem à Índia, procurando repetir a experiência de seu mestre Pitágoras. Filóstrato descreve fatos da vida de Apolônio que são muito semelhantes aos da vida de Cristo: i) seu nascimento foi informado a sua mãe por um ser sobrenatural; ii) ele nasceu de maneira miraculosa e foi um jovem muito precoce; iii) na idade adulta, dedicou-se à pregação itinerante, conclamando seus ouvintes a viver uma vida espiritual, desprezando as coisas materiais; iv) reuniu um grupo de discípulos, que acreditavam ser ele um ser divino; v) realizou diversos milagres, curando doentes, exorcizando demônios e ressuscitando mortos; v) suas ideias e atitudes the proporcionaram inimigos, que o entregaram às autoridades romanas para ser julgado; vi) depois de sepultado, retornou ao mundo para convencer seus seguidores de que não estava morto, mas vivia no reino celeste. Na Antiguidade, Apolônio foi visto como um herói do movimento anticristão e combatido por Eusébio e Lactâncio. No s. XVI, surgiu um grande interesse por Apolônio na Europa, mas prevaleceu ali a perspectiva da Igreja, que o considerava um mágico demoníaco e um grande inimigo do cristianismo. Mas as comparações entre Apolônio e Jesus se tornaram comuns nos séculos XVII e XVIII, no contexto da polêmica sobre o cristianismo. Diversos iluministas deístas e anticatólicos viam Apolônio como um precursor de suas próprias ideias éticas e religiosas, um proponente de uma religião racional e universal. Essas comparações continuaram no s. XX.

${ }^{18}$ Mártir Justino foi um apologista cristão do s. ii d. C. Foi martirizado, ao lado de alguns de seus estudantes e é venerado como santo pela Igreja Católica Romana, pela Igreja Anglicana e pela Igreja Ortodoxa do Oriente. Entre outras obras, escreveu uma Primeira apologia, endereçada ao imperador Antoninus Pius e uma Segunda apologia, endereçada ao senado romano. É-lhe também atribuída falsamente a autoria da Cohortatione ad Graecos (Exortação aos gregos), obra que, como veremos a seguir, foi citada por Leroux para explicar as ligações de Pitágoras com o dito de Paulo. Atualmente a autoria da Exortação é atribuída a um autor anônimo, como Pseudo Justino.
} 
de todas as coisas, luz no céu, pai de todos os seres, alma e alento de tudo o que existe, motor de todas as esferas e de todas as existências (PITÁGORAS apud PSEUDO JUSTINO, Cohortatione ad Graecos, c. xix, apud LEROUX, 1840, p. 454-5).

Como podemos ver pela exposição acima, Leroux não só confere grande importância ao dito de Paulo, mas também faz uma ligação entre esse dito e a filosofia de Pitágoras, utilizando como ponte as ideias de Apolônio. A concepção das relações entre Deus e o mundo são, porém, problemáticas. Com efeito, o tom geral da última das três passagens de Da humanidade parece identificar Deus e o mundo criado e por causa disso Leroux foi acusado de panteísta. Ele, porém, nunca aceitou essa denominação. No estudo que fizemos a esse respeito, concluímos que Leroux era de fato panenteísta, ou seja, defendia que Deus penetrava toda a criação, mas sem identificar-se com ela. Por motivos de espaço, não poderemos discutir esse ponto aqui.

De qualquer modo podemos constatar que, com exceção da referência a Apolônio, as semelhanças entre a terceira passagem de Leroux relativa à frase latina de Paulo e a terceira seção de Certeza Humana são inegáveis. Tudo indica que a fonte de inspiração de Figueiredo, ao escrever a última parte desse artigo, foi de fato Leroux. Se fizermos uma comparação, veremos com clareza que Figueiredo seguiu o fio do raciocínio desse pensador francês, estabelecendo uma ligação entre o dito de Paulo e a filosofia de Pitágoras. Mas cada um fez isso à sua maneira, para atender a seus próprios objetivos. Existe, assim, uma diferença entre Figueiredo e Leroux: ela está em que o primeiro articula o dito de Paulo e a filosofia de Pitágoras com a categoria cousiniana de relação para chegar à conclusão da presença divina no mundo criado, enquanto o segundo não realiza esse movimento, chegando diretamente a tal presença. Ora, assim como Leroux foi acusado de panteísta em virtude da sua concepção das relações entre Deus e o mundo criado, Figueiredo também deixou o flanco aberto para o mesmo tipo de acusação. A hipótese do panteísmo figueirediano ficaria reforçada pelo fato de o brasileiro ter considerado os conceitos de infinito e finito como correlativos, o que parece implicar que Deus - o infinito - e o mundo - o finito - só existem enquanto relacionados um ao outro, produzindo, ao fim e ao cabo, um resultado semelhante ao do panteísmo que identifica Deus com o mundo criado. Cousin também enfrentou o mesmo problema, sendo acusado de panteísta em virtude de sua concepção das relações entre o infinito e o finito. Não foi em vão que Vamireh Chacon acusou Figueiredo de ter aderido a um panteísmo idealista incompatível com a ideia de criação (CHACON, 1965, p. 110-6). Quanto à maneira de lidar com essa acusação, Cousin e Leroux sempre se recusaram a aceitá-la, o que nos leva a classificá-los como panenteístas. Figueiredo não se manifestou claramente a esse respeito, mas suas ligações com Cousin e Leroux fazem supor que ele também seria panenteísta. ${ }^{19}$ Infelizmente, por motivos de espaço, não poderemos levar adiante essa discussão no presente texto.

Com base nas doutrinas até agora expostas, podemos concluir, com Figueiredo, que não há verdade absoluta e que toda verdade é humana. A certeza também não é absoluta, mas simplesmente humana. E a própria ideia de realidade constitui uma criação do ser humano. Mas achamos importante destacar aqui a necessidade de uma pequena qualificação a ser feita na doutrina de Figueiredo. De fato, num dado momento da discussão, ele afirma que todo conhecimento humano é subjetivo e, num momento posterior, ele acrescenta que a certeza humana é ao mesmo tempo objetiva e subjetiva. Isso significa que o conhecimento humano também é simulta-

\footnotetext{
${ }^{19}$ O infinito deísmo do marquês de Maricá tem sido tradicionalmente interpretado como uma forma de panteímo, mas acreditamos que ele também é partidário do panenteísmo. Ver, a esse respeito, a seção 3.2.6.4.8.2, no segundo volume de nossa História da Filosofia do Brasil. A ruptura iluminista (1808-1843).
} 
neamente subjetivo e objetivo, gerando um conflito com a primeira afirmação. Parece-nos que esse conflito é aparente, revelando apenas uma imprecisão terminológica por parte de nosso autor. No início da demonstração, era importante enfatizar o caráter subjetivo do nosso conhecimento. Mas depois, à medida que o argumento se desenvolvia, era mais importante ainda enfatizar o caráter duplamente subjetivo e objetivo do nosso conhecimento, para preparar a solução figueirediana à controvérsia entre racionalismo e sensualismo. $\mathrm{E}$ o argumento como um todo deixa claro que é esse caráter duplo que caracteriza de fato o nosso conhecimento.

As posições assumidas acima nos permitem entender melhor as críticas que Figueiredo faz, na segunda parte de Certeza Humana, aos sistemas do ceticismo e do dogmatismo, procurando mostrar as suas respectivas falhas. Para criticar o ceticismo, ele se concentra apenas no argumento de Jouffroy a respeito da circularidade da demonstração feita pela inteligência a respeito da sua própria legitimidade. Jouffroy chama a posição resultante de ceticismo de direito ou ceticismo absoluto. Figueiredo a chama de ceticismo transcendente. Sua refutação do mesmo consiste em aplicar o argumento da circularidade à própria demonstração de Jouffroy, alegando que, ao provar a impossibilidade da inteligência em garantir sua própria legitimidade, já estamos pressupondo a própria legitimidade da inteligência. Em outras palavras, a demonstração de circularidade é ela também circular. Isso torna o argumento do ceticismo absoluto um contrassenso. Figueiredo também se recusa a admitir a existência de verdades absolutas com base na legitimidade do princípio de contradição, como faz Jouffroy. Figueiredo contesta esse procedimento, reduzindo o princípio de contradição a uma operação da inteligência humana contingente, que não tem condições de acessar verdades absolutas. Com efeito, se tudo depende da nossa inteligência humana contingente, então a própria noção de verdade absoluta, criada por essa mesma inteligência, é subjetiva e contingente também. Nesse caso, todas as verdades são relativas. A crítica de Figueiredo ao ceticismo de Jouffroy, todavia, é incompleta, pois ele não leva em conta a refutação do ceticismo feita por esse último em seus textos (ver JOUFFROY, 1843, p. 266-288; JOUFFROY, 1901, p. 162-71).

Sob a rubrica de dogmatismo, Figueiredo inclui o sensualismo, o idealismo, o materialismo, o panteísmo e até mesmo a filosofia de Cousin. Para criticá-los, ele se baseia no par de conceitos correlatos unidade/multiplicidade, alegando que todas as doutrinas dogmáticas negam a multiplicidade e enfatizam a unidade, abrindo assim o flanco ao ceticismo. De acordo com Figueiredo, é preciso manter os dois conceitos do par em questão, sob pena de incorrer em erro. O próprio Cousin é também acusado de dogmatismo, porque admite os pares ideias necessárias/ideias contingentes ou ideias absolutas/ideias relativas. Na verdade, como todo nosso conhecimento é subjetivo, não há verdades absolutas, de tal modo que só há ideias contingentes e relativas. Além disso, Cousin também se equivoca em sua teoria das apercepções puras. De acordo com tal teoria, como vimos, o pensamento humano possui dois momentos, o da espontaneidade e o da reflexão. Pela primeira, o ser humano acessa diretamente, ainda que de maneira confusa, o finito (eu), o infinito (não-eu) e sua relação. Essas são as apercepções puras. Pela reflexão, essas ideias são esclarecidas e organizadas, mas nada é acrescentado ao que veio da espontaneidade. Em virtude disso, as ideias de finito, infinito e sua relação são impessoais e independentes do eu. Como tais ideias constituem a razão humana, Cousin conclui, contra Kant e sua escola, que a razão humana é independente do eu e corresponde à substância verdadeira, à essência absoluta.

Figueiredo, que vê de maneira diferente a articulação entre espontaneidade e reflexão, se recusa a admitir isso, alegando que a razão humana não é independente da espontaneidade do eu, que constitui um ponto de vista abstrato de si mesmo. Embora o argumento tenha sido muito pouco desenvolvido, ele parece indicar que, para Figueiredo, a razão humana não é im- 
pessoal, como quer Cousin. Se todo conhecimento depende da percepção de uma relação, então tanto o momento da espontaneidade como o da reflexão envolvem relações. O próprio eu só existe como tal em uma relação com os objetos que percebe, de tal modo que, para ser pensado isoladamente enquanto conceito, não passa de um ponto de vista abstrato de si mesmo.

Em síntese, constatamos que, nos textos mencionados, Figueiredo discute complexos assuntos filosóficos de maneira bastante resumida e certamente com lacunas nas definições e demonstrações. Para tornar efetivamente clara a sua posição nas questões discutidas, ele deveria ter escrito um pequeno tratado de filosofia. Mas isso não aconteceu, devido à sua formação e às circunstâncias em que se encontrava. Figueiredo nos apresenta no máximo um programa de investigação, sem desenvolvê-lo e sem justificá-lo em detalhes. Tivemos de nos conformar com isso e tentar avançar uma interpretação razoável de suas ideias com base nos poucos dados disponíveis. Ora, esses últimos apontam na direção da adoção de uma posição predominantemente empirista por parte de Figueiredo. Com efeito, ao admitir apenas duas fontes para o nosso conhecimento, a sensação e a reflexão, ele aponta na direção do empirismo. Isso fica reforçado pela sua tese de todo nosso conhecimento depende da percepção de uma relação, que permite à nossa inteligência formular inicialmente um juízo imediato e, depois, por meio da combinação de vários juízos imediatos, chegar à elaboração de um juízo mediato. A dependência de nosso conhecimento com respeito à experiência sensorial é bastante clara aqui. E a ênfase na importância das relações como determinantes da existência dos termos correlativos confere uma certa originalidade a esse tipo de empirismo, que vê presentes no nosso conhecimento tanto a dimensão objetiva da sensação como a dimensão subjetiva da reflexão. Isso leva Figueiredo a fazer a crítica tanto do sensualismo como do idealismo, já que cada um desses sistemas enfatiza apenas uma das dimensões envolvidas em detrimento da outra.

Em consonância com a perspectiva acima, Figueiredo reconhece que todo conhecimento humano é subjetivo e que não há verdades absolutas, e sim verdades relativas. $\mathrm{E}$, ao denunciar a inexistência de uma linguagem filosófica adequada para expressar essas verdades, Figueiredo fica à vontade para explicar as intermináveis discussões filosóficas apelando ao conceito lockiano de logomaquia. Mas o tom geral de suas afirmações o associa a alguma forma de relativismo ou de probabilismo moderado. Pena que, por algum motivo que desconhecemos, Figueiredo não tenha publicado o terceiro artigo prometido ao final de Processos Lógicos do Espírito Humano, que explicaria como aplicar o método filosófico capaz de garantir a certeza humana obtida a partir da experiência sensorial e trabalhada pelo raciocínio.

Consideramos importante observar aqui que a posição empirista de Figueiredo não constitui o único aspecto relevante de sua filosofia. Ela é complementada por uma perspectiva espiritualista, decorrente de sua adesão às principais doutrinas cristãs. Por motivos de espaço, não iremos detalhar esse ponto aqui, pois isso envolveria levar em consideração outros artigos e alguns folhetins de Figueiredo. O que podemos dizer, a título de rápida informação, sem entrar em detalhes, é que Figueiredo parece ter adotado ideias semelhantes à de Lamennais, reconhecendo com esse último que o destino do ser humano é aproximar-se cada vez mais de Deus. Em virtude disso, devemos respeitar e ajudar aos outros no cumprimento de seus respectivos destinos, de acordo com as ideias cristãs de amor ao próximo, justiça e caridade (FIGUEIREDO, 1950c). Além disso, nos folhetins de 05/11/1855 e de 10/11/1856, ambos comentando o dia de finados, Figueiredo afirma que o sentimento de ternura pelos mortos, representado por essa data, constitui um dos mais sólidos alicerces da crença na imortalidade da alma. Essa crença é consolidada pelas ideias de ordem e justiça $E$ a revelação confirma essa crença sublime, inata, fonte da moral. Ao fazer uma análise do Ensaio sobre a Providência, de Bersot, publicada no folhetim de 05/05/1856, Figueiredo elogia esse autor como tendo sido um dos 
que melhor compreenderam a questão. Ali, Bersot afirma que a Providência é visível na natureza e necessária à ordem moral. O ser humano é fraco no meio das coisas transitórias, mas forte no meio das coisas eternas. Possuímos uma faculdade que nos arranca da terra e nos eleva ao mundo divino. Figueiredo subscreve essas ideias, afirmando que Bersot nos revela a Providência em todos os seus aspectos divinos. Por fim, no importante folhetim de 22/06/1857, Figueiredo alega que a perfeita harmonia que o cristianismo estabelece entre Deus e o ser humano já é suficiente para atribuir origem divina a essa doutrina. Para ele, só o cristianismo concebe o ser humano como inteligente e livre, como dotado de espírito e coração. Com isso, o cristianismo reconhece no homem duas partes distintas formando um todo unitário. Figueiredo ainda acrescenta que o nosso senso íntimo demonstra melhor do que o raciocínio e nos mostra a reciprocidade entre Deus e o ser humano, tanto no domínio das ideias como no domínio dos sentimentos. O ser humano sabe que vem de Deus e que avança para Deus. Nessa perspectiva, o homem é o sacerdote da criação. E podemos constatar isso ao testemunhar o espetáculo do culto religioso. Todos os folhetins mencionados foram publicados no Diário de Pernambuco. ${ }^{20}$ Isso nos parece suficiente para dar uma noção da adesão de Figueiredo às principais doutrinas cristãs que predominavam no Brasil de seu tempo.

Pelo que expusemos até agora a respeito das ideias filosóficas de Figueiredo em teoria do conhecimento, fica claro que ele, ao invés de partidário do espiritualismo eclético cousiniano, foi mais um defensor do empirismo espiritualista que predominou entre nós na primeira metade do s. xix. Esse termo, que substitui o tradicional empirismo mitigado, foi por nós criado para caracterizar toda posição filosófica que envolve, por um lado, uma adesão a uma forma de empirismo ao estilo lockiano e, por outro, uma associação desse empirismo com doutrinas espiritualistas, que, no caso brasileiro, se confundem com as doutrinas católicas tradicionais. Isso significa que, apesar da ligação que os historiadores da filosofia brasileira têm estabelecido entre as ideias de Figueiredo e as de Cousin, tal ligação é muito fraca e pode ter ocorrido apenas na breve primeira fase de seu pensamento. Mesmo assim, não temos condições de saber até que ponto Figueiredo foi um espiritualista eclético em tal fase, porque só temos notícia do artigo do Diário de Pernambuco, em que divulgava na época a sua tradução do Curso de História da Filosofia. Já na segunda fase de seu pensamento, Figueiredo revelou independência em relação ao espiritualismo eclético, tendo formulado inclusive fortes críticas a Cousin e a Jouffroy.

Desse modo, em que pese à tradicional ligação que seus intérpretes fazem entre suas ideias e o ecletismo cousiniano, Figueiredo ainda se revela um partidário do empirismo espiritualista que constituiu a doutrina dominante entre nós na primeira metade do s. xix. ${ }^{21}$ Isso significa que, apesar de seu contato com o ecletismo espiritualista, Figueiredo se manteve fiel nesse ponto à tradição representada por pensadores que o precederam ou que foram seus contemporâneos, como Pinheiro Ferreira, Padre Feijó, Monte Alverne, Maricá e Miranda Rego. E, como veremos mais adiante, Figueiredo ainda apresenta algumas afinidades com Maricá em outros aspectos de seu pensamento.

De um modo geral, as doutrinas acima possuem semelhanças com as de Locke, e, em virtude disso, passaremos a uma comparação entre as ideias desse pensador britânico e as de Figueiredo. A esse respeito, podemos dizer que encontramos uma boa convergência entre as ideias de ambos, principalmente nas linhas gerais das respectivas filosofias, embora haja algumas divergências em questões de detalhe. Em primeiro lugar, podemos dizer que, para

\footnotetext{
20 Para acessar esses folhetins, ver os números do Diário de Pernambuco nas datas correspondentes, disponíveis no sítio University of Florida Digital Collections, no endereço <https://ufdc.ufl.edu/AA00011611/07417/allvolumes>. Acesso em fevereiro de 2020.

${ }^{21}$ Ver, a esse respeito, o $2^{\circ}$ volume de nossa História da Filosofia do Brasil, relativo ao período da Ruptura lluminista, que vai de 1808 a 1843, principalmente a seção 4.5.1.2.
} 
ambos, todos os nossos conhecimentos são subjetivos e provêm da experiência. As seguintes qualificações, contudo, se impõem, em virtude das diferenças nas maneiras pelas quais eles concebem esse fato. No caso de Locke, o conhecimento é a percepção de uma relação de acordo ou desacordo entre duas ideias provenientes da experiência. No caso de Figueiredo, o conhecimento é a percepção de uma ideia, a qual equivale à percepção de uma relação entre dois termos. Essas diferenças serão desenvolvidas mais abaixo. Nesse ponto, basta-nos observar que, nos dois casos, fica clara a convergência de ambos em considerar a origem sensorial e o caráter subjetivo de nossos conhecimentos, sem a possibilidade de apelo a uma ontologia intuitivamente obtida a partir da introspecção, como acontece com a teoria das apercepções puras de Cousin.

Em segundo lugar, Figueiredo e Locke admitem duas fontes para o nosso conhecimento, a sensação e a reflexão. Aqui também há qualificações a serem feitas. No caso de Locke, a sensação nos fornece ideias simples, as quais propiciam o material para a elaboração posterior das ideias de reflexão. No caso de Figueiredo, a sensação não nos oferece ideias simples, mas sim percepções de relações entre termos, as quais podem ser expressas através de juízos imediatos, que depois serão utilizados como material para a construção dos juízos mediatos com o auxílio da reflexão.

Em terceiro lugar, pelo fato de considerarem que todo o conhecimento provém da experiência, ambos rejeitam as ideias inatas. Todavia, no caso de Locke, a rejeição é explícita e constitui um dos pilares de sua filosofia. Já no caso de Figueiredo, essa rejeição é implícita e não foi discutida nos artigos relevantes.

Em quarto lugar, Locke adota três categorias ontológicas em sua filosofia, ao alegar que todas as nossas ideias complexas podem ser de três tipos, a saber, a substância, os modos e as relações. Mas ele apenas estuda em detalhe as categorias de substância e modo, deixando a categoria de relação praticamente a descoberto. ${ }^{22}$ Figueiredo, de seu lado, adota como categoria ontológica apenas a de relação, sem fazer referência às duas outras. Isso parece implicar que as substâncias e os modos nos são dados através de relações. Para formular essa hipótese, Figueiredo parece ter-se inspirado não em Locke, mas em Cousin, cuja ontologia trabalha com pares de conceitos correlativos, de tal modo que nosso conhecimento se dá a partir das relações envolvidas por tais conceitos. Mas, em que pese ao tratamento pouco detalhado da questão, Figueiredo utilizou essa ideia de maneira original, pois, por um lado se afastou de Cousin, ao rejeitar as apercepções puras, e, por outro, se afastou também de Locke, ao reduzir nosso conhecimento apenas à percepção de relações.

Em quinto lugar, Locke adere ao conceptualismo, ao admitir que, embora somente os indivíduos sejam reais, eles podem ser pensados por meio de entidades mentais que atuam como conceitos universais. Figueiredo, por sua vez, adota uma posição que pode ao menos ser caracterizada como pró-conceptualista, pois ele distingue a ideia do juízo e admite implicitamente as distinções entre ideia e abstração, entre existência na relação percebida e existência abstrata na mente. Com isso, ele admite, à sua maneira, que somente existem percepções individuais de relações entre termos, mas que os termos de tais relações podem ser abstraídos das mesmas e pensados isoladamente, sem atribuição de existência.

Em sexto lugar, ambos destacam a importância de uma linguagem científica adequada para a aquisição do conhecimento, para evitar que as disputas filosóficas se reduzam a meras disputas de palavras. Mas com a qualificação de que ambos diferem na concepção do que seria essa linguagem adequada, uma vez que Locke enfatiza as essên-

22 Sobre as categorias ontológicas de Locke, ver (STUART, 2013, p. 1-32). 
cias nominais que constituiriam o vocabulário da mesma, enquanto Figueiredo se concentra explicitamente não nas ideias, mas sim nos juízos imediatos e mediatos que fariam parte dessa linguagem.

Em sétimo lugar, ambos têm dificuldades em justificar a existência do mundo exterior, em virtude do idealismo epistemológico por eles adotado. Em Locke, nosso conhecimento do mundo exterior está limitado ao conhecimento que temos de suas qualidades sensíveis, revelando-se assim probabilístico e inferior ao conhecimento que temos de nós mesmos e de Deus; em Figueiredo, a nossa crença no mundo exterior resulta da série de relações entre nossa inteligência e algo exterior a nós, relações essas que são assumidas como válidas sem maiores esclarecimentos nos artigos considerados.

Em oitavo e último lugar, ambos consideram a fé religiosa muito importante para as nossas vidas, acrescentando assim uma dimensão espiritualista aos seus respectivos empirismos. Mas aqui também mediante a qualificação de que Locke acreditava haver sérios limites àquilo que poderia ser justificado pela fé, enquanto Figueiredo não se preocupou com esse problema e aparentemente não via tantos limites assim no que diz respeito ao poder justificador da fé.

A única diferença mais explícita entre os dois autores está em que Locke critica o raciocínio silogístico, considerando-o supérfluo e inadequado para o avanço do nosso conhecimento. Figueiredo, em oposição, aceita a doutrina do silogismo, considerando-a um instrumento adequado para o avanço do nosso conhecimento. É verdade que, no início da terceira parte de Certeza Humana, ele identifica uma limitação no silogismo, que possui uma base que não pode ser demonstrada sem cairmos em paralogismo. Mas isso parece significar para ele que a obtenção das primeiras verdades não é realizada através de silogismos, e sim através da experiência sensorial, que nos proporciona a percepção de relações. Uma vez obtidas essas verdades, porém, elas podem ser utilizadas como premissas de silogismos. Apesar das qualificações feitas em todos os casos acima e apesar da oposição entre os dois pensadores na questão do silogismo, fica claro que isso não é suficiente para afastar um do outro radicalmente. Com efeito, em todos os demais aspectos considerados, as posições de Locke e Figueiredo convergem em direção à posição metodológica e doutrinária comum que temos designado como empirismo espiritualista. Nessa perspectiva, ambos podem ser considerados pertencentes a uma mesma linha de pensamento.

Muitas das qualificações apontadas acima correspondem a divergências implícitas entre os dois autores, principalmente porque Figueiredo escreveu apenas textos curtos sobre teoria do conhecimento, deixando muita coisa de lado, ao passo que Locke escreveu mais de uma obra a respeito, desenvolvendo uma série de detalhes que não foram considerados pelo brasileiro. Faltam em Figueiredo a consideração e a discussão dos seguintes pontos que encontramos facilmente em Locke: i) uma descrição detalhada das operações da mente ao lidar com a sensação e a reflexão; ii) uma distinção explícita entre experiência interna e externa; iii) uma análise dos elementos constitutivos dos juízos imediatos e mediatos, que provavelmente o levaria a uma distinção entre ideias simples e complexas; iv) um apelo às categorias de substância e modo para classificar nossas ideias complexas; v) uma distinção entre qualidades primárias e secundárias; vi) uma distinção entre essências reais e nominais; etc. É bastante provável que Figueiredo não chegasse às mesmas conclusões de Locke ao analisar esses tópicos, mas o que importa destacar aqui é o fato de que, mesmo assim, seu estudo da questão do conhecimento aponta na direção de uma combinação entre o empirismo e o espiritualismo, ao estilo de Locke, apesar de o brasileiro não ter justificado sua posição de maneira completa. 


\section{Observações finais}

Ao final do presente artigo, esperamos ter despertado a atenção do leitor para alguns aspectos da vida e da produção filosófica de Antônio Pedro de Figueiredo, estimulando-o a aprofundar os estudos a respeito do pensamento desse autor. É impressionante como esse mulato de origem humilde, praticamente abandonado à própria sorte em Recife, conseguiu abrigo junto aos carmelitas e, dedicando-se aos estudos como autodidata, conseguiu uma formação humanística acima da média da época.

O mais impressionante é como ele conseguiu superar todas as limitações sociais e os preconceitos raciais de sua época, expressando suas ideias por escrito. É verdade que com isso ele acabou despertando a animosidade de alguns adversários, que não se acanharam em apelidá-lo de ridículo Cousin mulato. Mas também é verdade que, também graças à sua postura corajosa, acabou ocupando uma posição de respeito junto a uma parte da elite intelectual de sua época. Isso é uma prova de que o autodidatismo, pelo menos no caso dele, não constituiu necessariamente um sinal de incompetência filosófica. Além disso, a atuação intelectual de Figueiredo faz suspeitar que, tivesse ele nascido em condições materiais mais favoráveis, teria conseguido maiores realizações ainda.

Figueiredo escreveu muito e sobre os mais variados assuntos, principalmente sob a forma de trabalhos esparsos. Mesmo assim, revelou certa unidade de pensamento do ponto de vista da filosofia, tendo desenvolvido suas ideias a partir de teoria do conhecimento idealista ao modelo de Locke, aqui exposta. Apesar de sofrer nesse campo a influência deste último e de outros autores, como Aristóteles, Cousin, Jouffroy e Leroux, Figueiredo foi capaz de realizara um trabalho filosófico pessoal e relativamente original, numa espécie de bricolagem das ideias provenientes dos autores mencionados. Foi uma pena que, por motivos desconhecidos, não completou a trilogia de artigos que tinha programado para expor a totalidade de suas ideias nesse campo. É claro que sua perspectiva tem de enfrentar dificuldades, já que se inspira nas ideias de autores que, eles também, têm de enfrentar dificuldades semelhantes. Por motivos de espaço, não tivemos oportunidade de discuti-las aqui. Mesmo assim, esperamos que a nossa exposição da teoria do conhecimento de Figueiredo anime o leitor a procurar conhecer os demais aspectos do seu pensamento, principalmente em filosofia moral e em filosofia política, as quais são elogiadas por quase todos os seus intérpretes quanto ao pragmatismo e realismo com que ele foi capaz de aplicá-las à situação brasileira de sua época.

\section{Referências}

BACON, F. De dignitate et augmentis scientiarum. In: The works of Francis Bacon. Collected and edicted by James Spedding, M.A., Robert Leslie Ellis, M.A., and Douglas Denon Heathl. Vol I, London: Longman and Co. and others, 1857.

CHACON, V. História das Ideias Socialistas no Brasil. Rio: Civilização Brasileira, 1965. (Coleção Retratos do Brasil, vol. 37). p. 110-6.

COUSIN, V. Cours de l'Histoire de la Philosophie. Histoire de la Philosophie du XVIII ${ }^{\text {me }}$ Siècle. Paris: Pichon et Didier, Éditeurs, 1829. Tome I.

COUSIN, V. Curso de História da Filosofia. Trad. A. P. de Figueiredo. Recife: Tipografia de M. F. de Faria, 1843-1845. 3 vols.

COUSIN, V. Fragmens Philosophiques. 2nde éd. Paris: Ladrange, 1833. 
COUSIN, Victor. Cours de l'histoire de la philosophie moderne. Deuxième série. Tome II. Nouvele éd. revue et corrigée. Paris: Didier; Ladrange, 1847.

DIÁRIO DE PERNAMBUCO. In: University of Florida Digital Collections. Disponível em: <https:// ufdc.ufl.edu/AA00011611/07417/allvolumes>. Acesso em: fevereiro de 2020.

FIGUEIREDO, A. Certeza Humana. In: . O Progresso. Revista Social, Litteraria e Scientífica. Reedição feita pelo Governo do Estado de Pernambuco. Prefácio de Amaro Quintas. Recife: Imprensa Oficial, 1950. p. 13-24. [1950a].

FIGUEIREDO, A. Processos Lógicos do Espírito Humano. In: . O Progresso Revista Social, Litteraria e Scientífica. Reedição feita pelo Governo do Estado de Pernambuco. Prefácio de Amaro Quintas. Recife: Imprensa Oficial, 1950. p. 83-92. [1950b].

FIGUEIREDO, A. Revista Literária - O Livro do Povo, de Lamennais. In: . O Progresso Revista Social, Litteraria e Scientífica. Reedição feita pelo Governo do Estado de Pernambuco. Prefácio de Amaro Quintas. Recife: Imprensa Oficial, 1950. p. 647-54. [1950c].

FREYRE, G. Nordeste. 5. ed. Rio de Janeiro: J. Olympio, 1985.

FREYRE, G. Um engenheiro francês no Brasil. Rio de Janeiro: J. Olimpio, 1940.

JOUFFROY, Th. Cours de droit naturel professé à la faculté des lettres de Paris par Th. Jouffroy. Tome deuxième. 2. éd. Paris: Librairie de L. Hachette, 1843.

JOUFFROY, Th. Mélanges Philosophiques, 7ème éd. Paris: Lib. Hachette et Cie., 1901.

LARA, T. A. As raízes cristãs do pensamento de Antônio Pedro de Figueiredo. 2. ed. Londrina: Editora da UEL, 2001. p. 29.

LAWLOR, H. J. St. Paul's Quotations from Epimenides. The Irish Church Quarterly, v. 9, n. 35, jul 1916. p. 180-93.

LEROUX, P. De l'humanité, de son principe, e de son avenir, ou se trouve exposée la vraie définition de la religion et ou l'on explique le sens, la suite et l'enchaînement du mosaisme et du christianisme. Tome Premier. Paris: Perrotin, Éditeur-Libraire, 1840.

MARGUTTI, P. História da Filosofia do Brasil. 2a Parte: A ruptura iluminista (1808-1843). S. Paulo: Loyola, 2020.

MARICÁ, Marquês de. Máximas, pensamentos e reflexões. Ministério da Cultura. Fundação Biblioteca Nacional. Departamento Nacional do Livro. Disponível em: <http://redememoria. bn.br/wp-content/uploads/ 2011/12/ maximas-pensamentos-e-reflexoes.pdf $>$. Acesso em: março 2015.

MARTINS, W. História da Inteligência Brasileira. v. II (1794-1855). 3. ed. São Paulo: T. A. Queiroz Editor, 1992.

NASCIMENTO, L. História da imprensa de Pernambuco (1821-1954). v. IV. Periódicos do Recife (1821-1850). Recife: Un. Federal de Pernambuco, 1969.

ORPHIC FRAGMENT 165 - Otto Kern. Disponível em: <http://www.hellenicgods.org/orphicfragment-165---otto-kern>. Acesso em: abril 2020.

ORPHIC RHAPSODIC THEOGONY. The Rise of the Six Kings. Disponível em: <http://www. hellenicgods.org/orphic-rhapsodies------24>. Acesso em: abril 2020.

ORSONI, G. O Progresso, une revue sociétaire au Brésil. Mémoire pour l'obtention du master d'études ibériques et nord-américaines. Paris: Un. Sorbonne Nouvelle, Paris III, 2013. Disponível em: <https://franc-dire.fr/sit-sed-ipsa-quia/>. 
ORTOLAN, J. De la souveraineté du peuple et des principes du gouvernement républicain moderne; cours ouvert à la Faculté de Droit de Paris, Le samedi 26 février 1848 par J. Ortolan, professeur à cette Faculté. Paris: Joubert, Libraire de la Cour de Cassation; Guillaumin et Cie, 1848.

SACRAMENTO BLAKE, A. V. A. Diccionario Bibliographico Brazileiro. Rio: Imprensa Nacional, v. 1, 1900.

\section{Sobre o autor}

\section{Paulo Roberto Margutti Pinto}

PhD em filosofia pela University of Edinbourgh. Professor titular da Faculdade Jesuíta de Filosofia e Teologia (BH).

Recebido em: 15/07/2020.

Aprovado em: 18/09/2020.
Received: 15/07/2020.

Approved: 18/09/2020. 